\title{
Paralaophonte harpagone sp. n. (Copepoda: Harpacticoida), a laophontid with an extremely specialised maxilliped
}

\author{
Hendrik Gheerardyna, *, Frank Fiers ${ }^{\mathrm{b}}$, Magda Vincxa ${ }^{\mathrm{a}}$, Marleen De Troch ${ }^{\mathrm{a}}$ \\ a Marine Biology Section, Ghent University, Sterre complex-Building S8, Krijgslaan 281, 9000 Gent, Belgium \\ b Royal Belgian Institute of Natural Sciences, Section of Recent Invertebrates, Vautierstraat 29, 1000 Brussel, \\ Belgium \\ * Corresponding author, e-mail: hendrik.gheerardyn@ugent.be
}

Received 20 April 2005 • Accepted 8 December 2005

\begin{abstract}
Paralaophonte harpagone sp. $\mathrm{n}$. is described from the coast of Kenya. The new species does not show any sexual dimorphism in the endopodite of P3 nor in the exopodites of P2 to P4. However, it is a true representative of the genus Paralaophonte by virtue of the typical sexually dimorphic P2 endopodite with its modified distal inner seta on the second endopodal segment. The most distinguishing feature of the new species is the robust, enlarged and specialised maxilliped, present in both sexes. This maxilliped is similar in robustness and position to the highly specialised maxilliped in the laophontid genus Namakosiramia Ho \& Perkins, 1977 the two members of which live as ectoparasites on holothurians. We can only speculate whether the specialised maxilliped of Paralaophonte harpagone sp. $\mathrm{n}$. is an adaptation to living in association with another invertebrate.
\end{abstract}

Keywords: Laophontidae; Paralaophonte harpagone sp. n.; specialised maxilliped

\section{Introduction}

The harpacticoid family Laophontidae T. Scott, 1905 is a large and heterogeneous group, at present including 63 genera (Huys and Lee 2000; Gheerardyn et al. 2006). Throughout the family, the maxilliped shows little variation from the condition in the type species, Laophonte cornuta Philippi, 1840. This type of maxilliped consists of a cylindrical syncoxa bearing up to 3 setae, a basis with a straight palmar and a convex outer margin, and an endopodal claw bearing one accessory seta at base. The maxillipeds are typically inserted close to each other on both sides of the longitudinal axis of the copepod. However, dimensions and firmness of the composing elements, i.e. syncoxa, basis and endopodal claw, can vary.

Nearly all members of the subfamily Esolinae Huys $\&$ Lee, 2000 have a slender maxilliped with an elongate basis and endopodal claw. Species of Echinolaophonte Nicholls, 1941 are also characterised by a long and slender maxilliped. The two species of the closely related genus Xanthilaophonte Fiers, 1991, living in close association with decapods (Fiers 1991), have strongerbuilt, robust maxillipeds. While in Robustunguis Fiers, 1992 the strong and large prehensile first leg grasps the bristles of the decapod host (Fiers 1992), this function may be performed mainly by the strong maxilliped in Xanthilaophonte. A well developed and strongly prehensile maxilliped permits the two species of Mictyricola Nicholls, 1957 to live commensally with land crabs (Nicholls 1957). Large and strongly built maxillipeds are also present in Raptolaophonte ardua Cottarelli \& Forniz, 1989 and Harrietella simulans (T. Scott, 1894), the latter living as an associate of wood-infesting Isopoda of the genus Limnoria (Pinkster 1968). A very strongly built maxilliped is encountered in the highly specialised members of the laophontid genus Namakosiramia Ho \& Perkins, 1977. The two species of this genus live as ectoparasites on holothurians; maxillipeds, $\mathrm{P} 1$ and $\mathrm{P} 2$ form powerful anchoring appendages used for clinging to the host (Ho and Perkins 1977; Huys 1988). 
A new species of Paralaophonte Lang, 1944 is described here. Its most distinguishing feature-apart from the absence of sexual dimorphism in the endopodite of $\mathrm{P} 3$ and the exopodites of $\mathrm{P} 2$ to $\mathrm{P} 4$ - is a particular robust, backwardly directed maxilliped.

\section{Material and methods}

Meiofauna samples were collected from dead coral fragments along the Kenyan coast. Epifauna from coral fragments and coral rubble was rinsed off over a $1 \mathrm{~mm}$ and a $32 \mu \mathrm{m}$ sieve. Shortly after collecting, a buffered formaldehyde solution was added to a final concentration of $4 \%$.

In the laboratory, samples were rinsed with a jet of freshwater over a $1 \mathrm{~mm}$ sieve, then decanted ten times over a $32 \mu \mathrm{m}$ sieve, subsequently centrifuged three times with Ludox HS40 (specific density 1.18), finally stained with Rose Bengal. Harpacticoid copepods were sorted out and counted using a Wild M5 binocular, and were stored in $75 \%$ ethanol.

Observations and drawings were made from whole and dissected specimens mounted in glycerine, using a light microscope (Leica DM LS) equipped with a drawing tube. Preparations were sealed with insulating varnish. In toto specimens were stored in $75 \%$ ethanol. Type specimens are deposited in the Invertebrate Collections of the Royal Belgian Institute of Natural Sciences (KBIN), Brussels.

The descriptive terminology is adopted from Huys et al. (1996). Abbreviations used in the text are: $\mathrm{A} 1=$ antennule; $\mathrm{A} 2$ = antenna; ae $=$ aesthetasc; enp = endopod; enp(exp)-1(2,3) = proximal (middle, distal) segment of a ramus; $\exp =$ exopod; $\mathrm{Mxp}=$ maxilliped; $\mathrm{P} 1-\mathrm{P} 6=$ first to sixth thoracopods.

\section{Systematics}

Family Laophontidae T. Scott, 1905

Subfamily Laophontinae T. Scott, 1905 sensu Huys and Lee (2000)

Genus Paralaophonte Lang, 1944

\section{Paralaophonte harpagone sp. $\mathrm{n}$.}

\section{Etymology}

The specific epithet is derived from the Latin noun harpago (= grappling hook), harpagone being the ablative form, and refers to the large maxilliped.

\section{Type material}

Holotype 9 on 1 slide (COP 4714, deposited in the Invertebrate Collections of the Royal Belgian Institute of Natural Sciences (KBIN), Brussels); western Indian Ocean, Kenyan coast, in front of village Kurwitu $\left(03^{\circ} 47^{\prime} \mathrm{S}, 39^{\circ} 49^{\prime} \mathrm{E}\right)$, from dead coral fragments, water depth less than $1 \mathrm{~m}$; 26 February 2002, leg. M. Raes.
Paratypes. (A) As holotype, except as follows: allotype $\delta$ dissected on 3 slides (COP 4715a-c); 2 우 and 2 गे 0 dissected on slides (COP 4716-COP 4719); 4 우, 4 $\widehat{\jmath}, 2$ CII, 1 CIII, 2 CIV and $1 q \mathrm{CV}$ preserved in $70 \%$ alcohol (COP 4720). (B) 1 q preserved in 70\% alcohol (COP 4721); western Indian Ocean, Kenyan coast, Watamu Marine Park ( $03^{\circ} 21^{\prime}$ S, $40^{\circ} 01^{\prime}$ E), from dead coral fragments, water depth 2-3 m; 27 February 2002, leg. M. Raes.

\section{Description of female}

Total body length $356-415 \mu \mathrm{m}(\mathrm{n}=7$; average $=395$ $\mu \mathrm{m}$; measured from anterior margin of rostrum to posterior margin of caudal rami). Largest width measured at cephalothorax just in front of insertion of Mxp: 137 $\mu \mathrm{m}$.

Rostrum (Fig. 2G) fused to cephalothorax, slightly longer than wide, with parallel margins and truncated at the tip; with a pair of sensilla anteriorly; dorsal surface clothed with minute spinules.

Habitus (Fig. 1A, B). Body depressed. Cephalothorax as long as wide, rounded anteriorly, posterolateral angles concave before insertion of Mxp. Largest width just in front of insertion of Mxp. Free prosomites and following two urosomites gradually tapering posteriorly; third urosomite slightly wider than second urosomite; following urosomites gradually tapering posteriorly. Pleural areas of free prosomites well developed and rounded with lobate posterolateral angles. Second and third urosomites fused to form genital double-somite. Genital double-somite with transverse surface ridge dorsally and laterally, indicating original segmentation; fused ventrally.

Integument of cephalothorax, pleurotergites of prosomites and urosomites, and dorsal surface of anal somite and caudal rami clothed with minute spinules; spinules somewhat larger in the pleural areas. Cephalothorax regularly ornamented with small sensilla. Posterodorsal margins of cephalothorax and free somites smooth with a number of small sensilla (not on penultimate urosomite). Lateral and posterodorsal margins of cephalothorax, free prosomites and urosomites clothed with slender spinules which are stronger in the pleural areas. Free prosomites and first urosomite bearing some stout spinules near transition of tergital and pleural areas.

Ventral surface (Fig. 4B) of genital double-somite smooth, except for some median striae. Copulatory pore minute, situated in middle of anterior somite. Ventral surface of following urosomites with some spinules laterally, smooth medially. Ventral surface of caudal rami smooth. Posteroventral margins of genital double-somite and of following urosomites bearing a row of strong spinules. 
Caudal rami (Fig. 4A) 1.5 times as long as wide; cylindrical with straight inner and outer margins. Inner margin bearing two transverse rows of long spinules. Setae I, II and III inserted in distal fourth of outer margin, seta VII in distal third. Setae IV and V not fused, both pinnate; all other setae naked.

Antennule (Fig. 2A) six-segmented; majority of setae long and slender; segments 1-3 dorsally clothed with minute spinules; segments 4-6 smooth. Segment 1 with spinular rows on inner, outer and distal margins. Segment 2 bearing a small blunt process along outer margin, and spinular rows along inner and outer margins. Segment 3 with some long spinules along inner margin. Armature formula: 1-[1], 2-[8], 3-[7], 4-[2+ ae], 5-[1], 6-[11+ ae].

Antenna (Fig. 2H). Coxa with 1 spinular row. Allobasis with 1 short and unipinnate abexopodal seta. Exp unisegmented and small, bearing 4 subequal bipinnate setae ( 2 laterally, 2 apically). Enp bearing 4 spinular rows; with following armature: subapically 2 spines and a slender seta, apically 2 strong spines, 3 geniculate setae, and 1 minute seta.

Mandible (Fig. 2D). Biting edge formed by several blunt teeth and a seta. Palp uniramous; medial seta plumose, 3 apical setae smooth.

Maxillule (Fig. 2E). Praecoxa with a rather short arthrite; bearing a spinular row on posterior surface and 1 seta on anterior surface; medial margin furnished with 8 setae/spines. Coxal endite with 1 seta and 1 curved, pinnate spine. Basal endite with 2 naked setae and 1 curved, pinnate spine. Endopod obsolete, represented by 3 setae. Exopod 1-segmented with 2 apical setae.

Maxilla (Fig. 2F). Syncoxa with 3 endites; with 1 row of spinules along outer and 1 along inner margin. Praecoxal endite small, with 1 seta. Both coxal endites with 1 strong, pinnate spine and 2 slender, naked setae. Allobasis drawn out into strong, slightly curved, distally pinnate claw; bearing 2 pinnate setae and 1 small, naked seta. Endopod obsolete, represented by 2 naked setae.

Maxilliped (Fig. 2K) robust; held laterally from the body, backwardly directed. Syncoxa robust; with 2 spinular rows and 1 naked seta. Basis robust; with 1 transverse row of spinules along outer margin; outer surface clothed with minute spinules; distal third of palmar margin markedly concave, bordered with 1 transverse row of stout spinules along the strongly sclerotised integument. Endopod strongly sclerotised, claw-shaped, unarmed and short (length equals one third of length of basis); with short seta at base.

P1 (Fig. 3A). Coxa cylindrical; with spinules along outer margin. Basis with 1 pinnate seta along outer margin; medial seta arising in middle of anterior surface; spinules along inner and outer margins; 1 anterior tube pore near articulation with coxa. Exp-1 with 1 unipinnate outer seta; exp-2 twice as long as exp-1, with 2 naked outer spines and 2 geniculate apical setae. Enp-1 twice as long as exp; with spinules along inner margin. Enp-2 with spinules along outer margin; with 1 strong, smooth claw and 1 minute, naked accessory seta.

P2-P4 (Fig. 3B-D). For setal formulae see Table 1. Exopodites 3-segmented, endopodites 2-segmented. Prae-coxae triangular with an outer row of small spinules. Coxae with rows of long spinules along outer margin. Bases with a spinular row near insertion of the long, slender, pinnate (P2) or naked (P3-P4) basal seta; and 1 anterior tube pore. Segments of endopodites and exopodites with pattern of spinules as figured.

Table 1: Paralaophonte harpagone sp. n., swimming leg setal formulae.

\begin{tabular}{llll}
\hline & P2 & P3 & P4 \\
Exp & 0.1 .123 & 0.1 .223 & 0.1 .222 \\
Enp & 0.220 & 0.220 & 0.120 \\
\hline
\end{tabular}

P5 (Fig. 2I) with exopod and baseoendopod separate; both anteriorly covered with spinules; margin of endopodal lobe with strong spinules. Basal seta arising from a cylindrical setophore with a tube pore proximally. Proximal spines of endopodal lobe strong and bipinnate; subapical and apical setae plumose. Exopod reaching far beyond baseoendopod; rounded; slightly longer than wide; bearing 4 setae (2 plumose, 2 naked), closely set in distal region.

P6 vestige (Fig. 4B) bearing 1 seta.

\section{Description of male}

Total body length $349-379 \mu \mathrm{m}(\mathrm{n}=7$; average $=366$ $\mu \mathrm{m}$; measured from anterior margin of rostrum to posterior margin of caudal rami). Largest width measured at cephalothorax just in front of insertion of Mxp: 114 $\mu \mathrm{m}$.

Habitus as in female. Second and third urosomites fully separated (Fig. 4C). Ventral surface of third urosomite with several rows of spinules laterally; smooth medially.

Antennule (Fig. 2B, C) 7-segmented; subchirocer. Segments 1 and 2 as in female. Armature formula: 1[1], 2-[9], 3-[7], 4-[2], 5-[11(?) + ae], 6-[1], 7-[10+ ae].

Mouthparts, P1, P3 and P4 as in female.

P2 (Fig. 3E). Exopod as in female. Distal inner seta of enp-2 strongly built in proximal half; with long hairs proximally, strong spinules medially and plumose distally.

P5 (Fig. 2J). Endopodal lobe of P5 obsolete; bearing 1 plumose seta with some spinules medially to it, spinules absent at opposite endopodal lobe. Basal part 
with a naked seta on a setophore, clothed with spinules. Exopodite oblong; about 2 times longer than wide; bearing 5 setae: 1 outer, 1 apical and 3 inner setae (outer seta smooth, other setae plumose). Outer margin and anterior surface with spinules.

P6 vestiges (Fig. 4C) asymmetrical. One vestige functional; one vestige fused to somite; outer distal corner with 1 plumose inner and 1 naked outer seta, each on a small pedestal.

\section{Copepodids}

Copepodid stages CII to CV (CI not found) all have a robust maxilliped; held laterally from the body (Figs. 1C, 2L). The syncoxal seta appears in the third copepodid stage.

\section{Variation}

Whereas females show almost no variation, males have a variable $\mathrm{P} 2$ exopodal armature. Most males have a left or right P2 with only 2 outer spines on exp-3 (Fig. 4D); the opposite leg consistently has a normal setal formula with 3 outer spines. The allotype has an aberrant P3 enp (1.220) (Fig. 4E) on the right side; another male paratype has a left and right $\mathrm{P} 3$ with an aberrant exopodal armature (0.1.122); a third male paratype has 6 exopodal setae on the right P5 (Fig. 4F).

\section{Discussion}

Paralaophonte harpagone sp. n. occupies a very distinct position in the genus Paralaophonte Lang, 1944 because of the absence of any trace of sexual dimorphism in the endopodite of $\mathrm{P} 3$ and the exopodites of $\mathrm{P} 2$ to P4. However, the new species is a true representative of the genus Paralaophonte by virtue of the typical sexually dimorphic $\mathrm{P} 2$ endopodite which is the major diagnostic feature of the genus. Nearly all members of Paralaophonte have a distinct sexually dimorphic three-segmented P3 endopodite bearing an outer apophysis on the second segment. As discussed in Wells et al. (1982), four species have the male P3 endopod only slightly modified, i.e. never 3-segmented: $P a$ ralaophonte perplexa (T. Scott, 1898), P. quaterspinata (Brian, 1917), P. innae Chislenko, 1977, and $P$. aenigmaticum Wells, Hicks \& Coull, 1982. Paralaophonte subterranea Lang, 1965 has been transferred to Loureirophonte Jakobi, 1953 in Fiers (1993). In most species of Paralaophonte, the males have a distinctly modified, strongly built P3 exopod, whereas the exopods of $\mathrm{P} 2$ and $\mathrm{P} 4$ show little or no modification. Only in a few species the exopod of P3 is little or not modified compared to the female: Paralaophonte macera (Sars, 1908) and P. spitzbergensis Mielke, 1974 with only stronger outer spines, $P$. innae with exopods as in female. Another new species of Paralaophonte, which is currently under study, shows the typical sexually dimorphic endopodites of P2 and P3, but lacks sexual dimorphism in the exopodites.

Mielke (1981) mentioned the several reduction tendencies in Paralaophonte, above all regarding the number of segments of the antennule, the number of exopodal segments of P1 and the chaetotaxy of the swimming legs. The present new species clearly exhibits these tendencies, in having only six antennular segments and two exopodal segments on P1. The chaetotaxy is highly reduced, without an outer seta on the endopodites of $\mathrm{P} 3$ and $\mathrm{P} 4$, enp- 2 of $\mathrm{P} 3$ bears only two inner setae, and exp-3 of $\mathrm{P} 4$ bears only two outer spines. Paralaophonte quaterspinata and $P$. innae also lack an outer seta on enp-2 of P3 but still have the outer seta on enp-2 of $\mathrm{P} 4$. Paralaophonte aenigmaticum lacks the outer seta on the endopodites of both P3 and $\mathrm{P} 4$, but bears three inner setae on enp-2 of P3. Paralaophonte aenigmaticum and P. panamensis Mielke, 1982 are the sole two species of Paralaophonte, apart from Paralaophonte harpagone sp. n., with only two outer spines on exp-3 of $\mathrm{P} 4$.

Paralaophonte Lang is a large genus currently containing 33 species (including the one described in this paper) (Lang 1948; Bodin 1997). The majority is benthic and freeliving, but three species are true associates of the common spider crab, Maja squinado (Herbst, 1788), namely Paralaophonte royi (Jakubisiak, 1932), P. majae Petkovski, 1964, and P. ormieresi Raibaut, 1968. However, none of them displays particular adaptations of body and appendages (Petkovski 1964; Raibaut 1968; personal observation of additional material of $P$. royi). Within the genus, Paralaophonte harpagone sp. $\mathrm{n}$. has a unique chaetotaxy, but the most distinguishing feature is the shape and position of the maxilliped, previously unseen in Paralaophonte. The shape and particularly the robustness of the maxilliped resemble the strongly developed maxilliped in the genus Namakosiramia Ho \& Perkins, 1977 (fig. 3F in Huys 1988; fig. 2F in Kim 1991). The latter consists of a robust syncoxa and basis, and a strong hook-like endopodite. The maxillipedal endopodite in $P$. harpagone sp. n., however, is distinctly shorter. In both Paralaophonte harpagone sp. $\mathrm{n}$. and Namakosiramia the maxillipeds are inserted near the lateral sides of the body and consequently are held almost entirely next to the body. However, the armature of the segments is different. While in Namakosiramia the syncoxa is asetose and the endopod bears two minute setae; in Paralaophonte harpagone sp. n. syncoxa and endopod each bear one seta (the endopodal one being minute). Originally, Namakosiramia californiensis Ho \& Perkins, 1977 was placed in a new Cyclopoida family. Ho (1986) concluded that it should have been placed in the 
Harpacticoida because of certain non-cyclopoid features. Huys (1988) redescribed the species and effectively allocated it to the Laophontidae. In 1991, Kim described a second species, Namakosiramia koreensis, based on specimens of both sexes. Still, the systematic position within the family remains unclear, due to the extremely specialised body shape, the far-reaching reduction of buccal and locomotory appendages, and the absence of sexually dimorphic structures of the legs.

Namakosiramia californiensis lives as an ectoparasite on the holothurian Stichopus parvimensis (collected off Palos Verdes, California) (Ho and Perkins 1977), while $N$. koreensis was collected from the body surfaces of two species of holothurians from Korean waters (Kim 1991). The maxilliped, P1 and P2 are powerful anchoring appendages for clinging to the host. All other postantennal appendages are strongly reduced in size and structure (Ho and Perkins 1977; Huys 1988).

Among the other Laophontidae, a maxilliped of comparable robustness and position is not encountered, except in the newly described species. Based solely on similarity in this homologous structure (i.e. the maxilliped), it would be hazardous to claim that Namakosiramia Ho \& Perkins, 1977 belongs to the lineage Paralaophonte Lang-Loureirophonte Jakobi. Namakosiramia is a valuable and distinctly defined genus with unique characteristics (e.g. absence of a process on segment 2 of A1, P2 stout and prehensile with exopodite forming a hook-like segment, P3-P5 vestigial). Furthermore, features which may clarify the relationship with Paralaophonte, i.e. the sexual dimorphism in the legs, are absent in the strongly reduced legs of Namakosiramia.

In the two samples containing Paralaophonte harpagone sp. n., no specimens were found attached to a possible invertebrate host (the $1 \mathrm{~mm}$ fraction contained mostly tanaidaceans and some small polychaetes, cumaceans and amphipods). Thus far, we can only speculate whether the robust maxilliped may permit the species to live as an associate of another invertebrate.

\section{Acknowledgements}

The first and last authors acknowledge grants, as aspirant and postdoctoral fellow, respectively, from the Fund for Scientific Research, FWO-Flanders, Belgium. The sampling campaign in Kenya was organised in the frame of the research project G.0199.03, "A comparative study of the meio-epifauna associated with tropical and cold-water coral reefs", sponsored by the same Fund for Scientific Research.

\section{References}

Bodin, P., 1997. Catalogue of the new marine harpacticoid copepods. Doc. Trav. Inst. Roy. Sci. Nat. Belg. 89, 1-304.

Fiers, F., 1991. Allocation of Laophonte trispinosa Sewell to Xanthilaophonte gen. nov. and the description of $X$. carcinicola spec. nov. (Harpacticoida: Laophontidae). Zool. Meded. Leiden 65(22), 287-312.

Fiers, F., 1992. Robustunguis gen. nov., a genus of decapod associated laophontids (Copepoda: Harpacticoida). Zool. Meded. Leiden 66(28), 399-412.

Fiers, F., 1993. The laophontid genus Loureirophonte Jakobi, 1953 (Copepoda, Harpacticoida). Zool. Meded. Leiden 67(14), 207-238.

Gheerardyn, H., Fiers, F., Vincx, M., De Troch, M., 2006. Peltidiphonte gen. n., a new taxon of Laophontidae (Copepoda: Harpacticoida) from coral substrates of the Indo-West Pacific Ocean. Hydrobiologia 553, 171-199.

Ho, J.-s., 1986. Phylogeny of Cyclopoida. Syllogeus 58, 177-183.

Ho, J.-s., Perkins, P.S., 1977. A new family of cyclopoid copepod (Namakosiramiidae) parasitic on holothurians from southern California. J. Parasitol. 63, 368-371.

Huys, R., 1988. On the identity of the Namakosiramiidae Ho \& Perkins 1977 (Crustacea, Copepoda), including a review of harpacticoid associates of Echinodermata. J. Nat. Hist. 22, 1517-1532.

Huys, R., Gee, J.M., Moore, C.G., Hamond, R., 1996. Marine and brackish water harpacticoid copepods. Part 1, in: Kermack, D.M., Barnes, R.S.K., Crothers, J.H. (Eds.), Synopses of the British Fauna (New Series), London, $352 \mathrm{pp}$.

Huys, R., Lee, W., 2000. Basal resolution of laophontid phylogeny and the paraphyly of Esola Edwards. Bull. Nat. Hist. Mus. (Zool.) 66, 49-107.

Kim, I.-H., 1991. A new species of Namakosiramia Ho \& Perkins parasitic on holothurians from Korea (Copepoda: Harpacticoida). Bull. Plankton Soc. Japan, Spec. Vol. 1991, 429-435.

Lang, K., 1948. Monographie der Harpacticiden I + II. Håkan Ohlssons Boktryckeri, Lund.

Mielke, W., 1981. Interstitielle Fauna von Galapagos. XXVIII. Laophontinae (Laophontidae), Ancorabolidae (Harpacticoida). Mikrofauna Meeresb. 84, 1-106.

Nicholls, A.G., 1957. Harpacticoid copepods commensal with crabs. Ann. Mag. Nat. Hist. 12(10), 896-904.

Petkovski, T.K., 1964. Bemerkenswerte Entomostraken aus Jugoslavien. Acta Mus. Maced. Sci. nat. 9(7-83), 147-181.

Pinkster, S., 1968. Harpacticoid copepods living in wood infested by Limnoria from France. Bull. Zool. Mus. Univ. Amsterdam 1(6), 53-65.

Raibaut, A., 1968. Paralaophonte ormieresi n. sp., copépode harpacticoïde trouvé sur les branchies de Maia squinado (Herbst) (Crustacea, Decapoda). Bull. Soc. Zool. Fr. 93(3), 451-457.

Wells, J.B.J., Hicks, G.R.F., Coull, B.C., 1982. Common harpacticoid copepods from New Zealand harbours and estuaries. N. Z. J. Zool. 9, 151-184. 


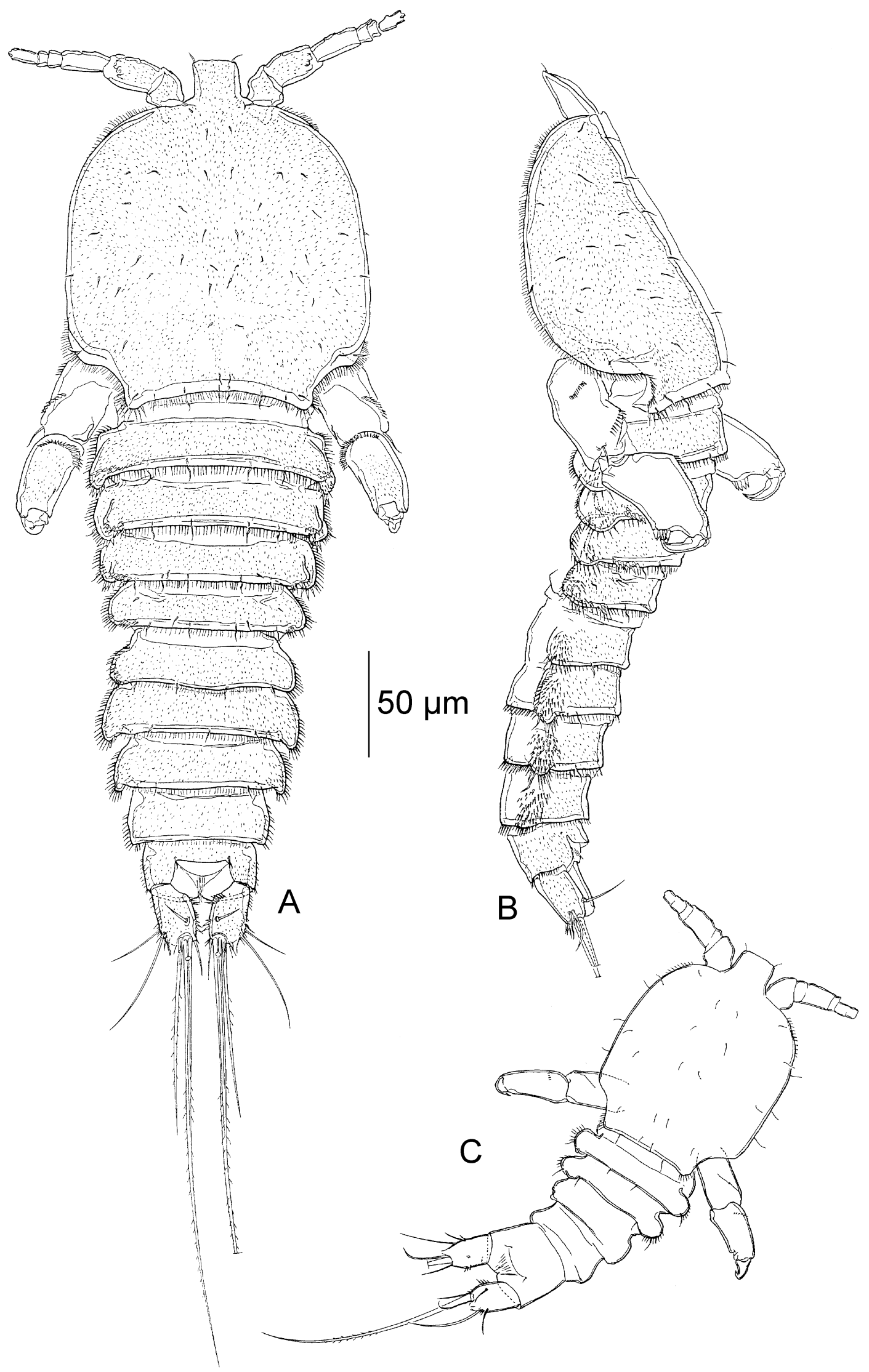

Fig. 1: Paralaophonte harpagone sp. n. (A) Female habitus, dorsal. (B) Female habitus, lateral: (C) Second copepodid, dorsal. 

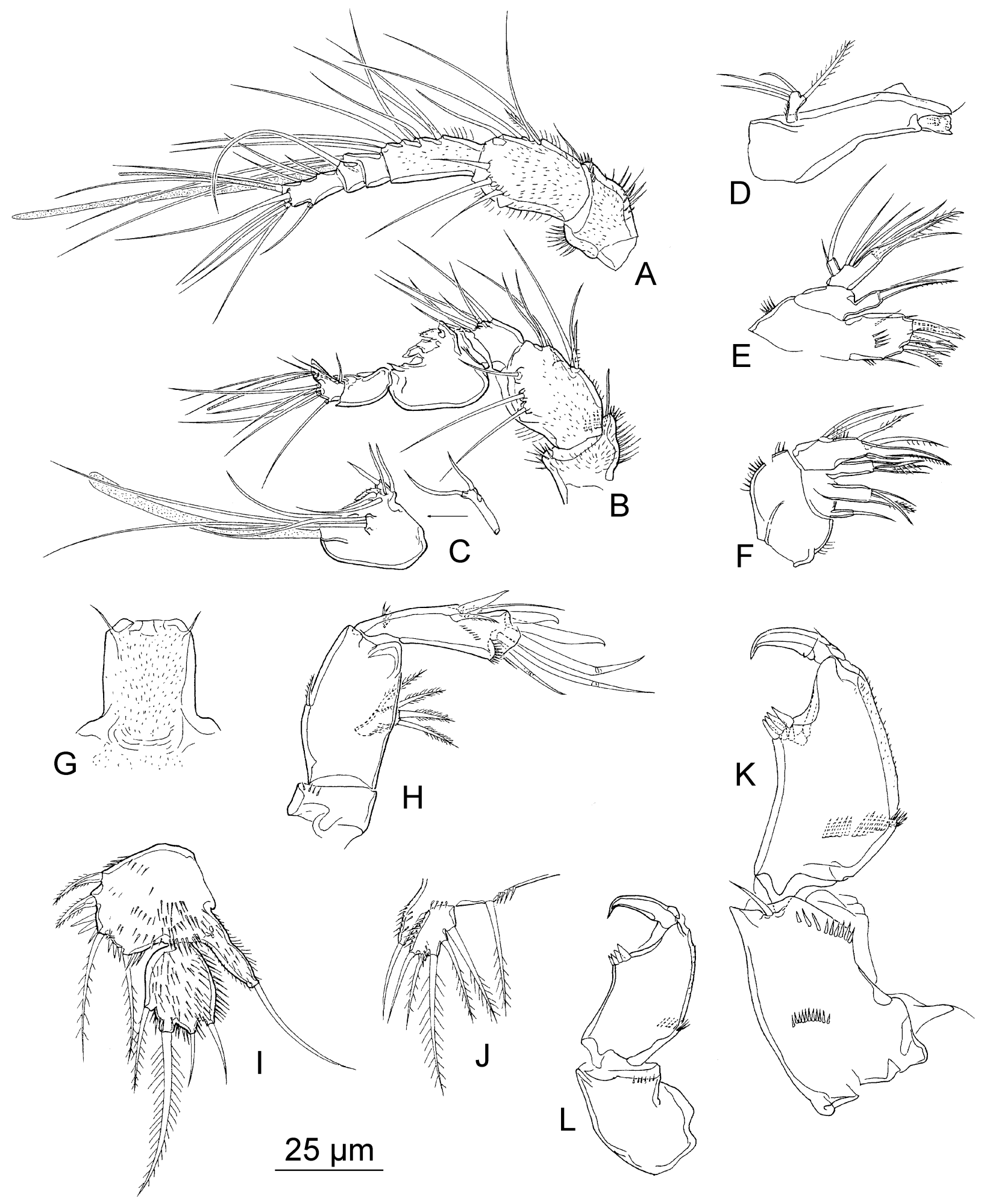

Fig. 2: Paralaophonte harpagone sp. n. (A) Female antennule, dorsal. (B) Left male antennule (armature of segments IV and V omitted), dorsal. (C) Right male antennule (segments IV and V), ventral. (D) Female mandible. (E) Female maxillule. (F) Female maxilla. (G) Female rostrum. dorsal. (H) Female antenna. (I) Female P5, anterior. (J) Male P5, anterior. (K) Female maxilliped. (L) Maxilliped of second copepodid . 


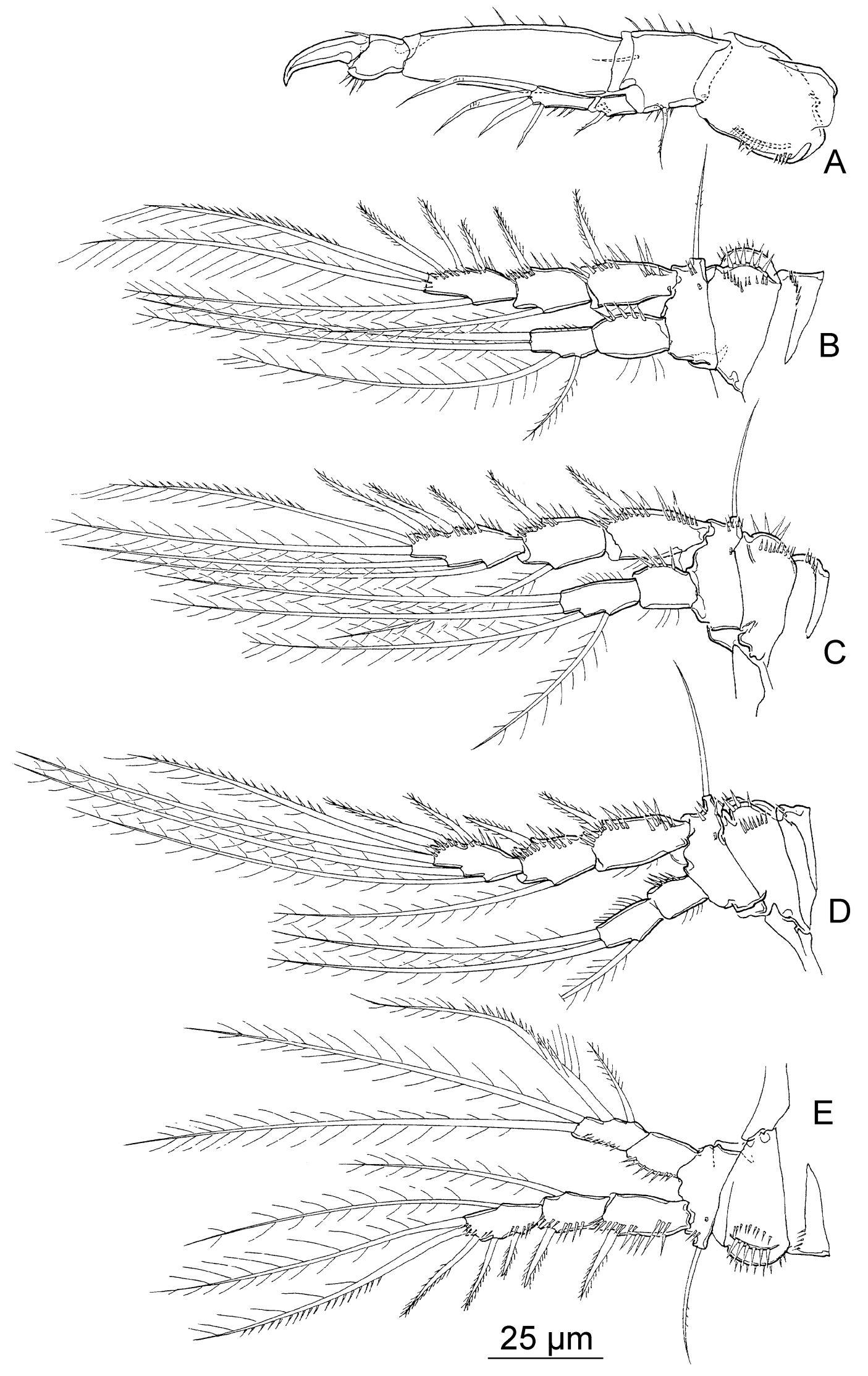

Fig. 3: Paralaophonte harpagone sp. n. (A) Female P1, posterior. (B) Female P2, anterior. (C) Female P3, anterior. (D) Female P4, anterior. (E) Male P2, anterior. 

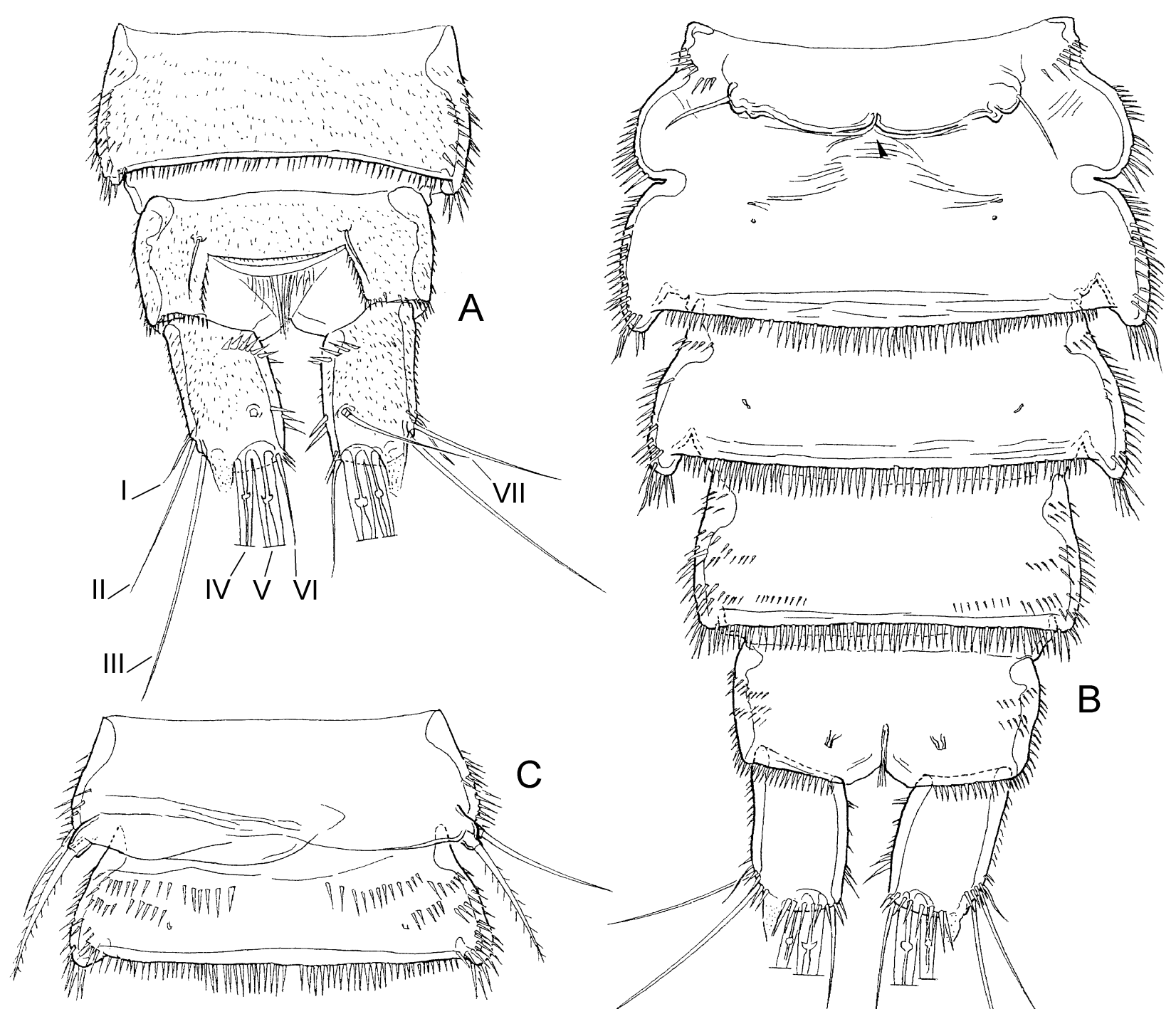

D
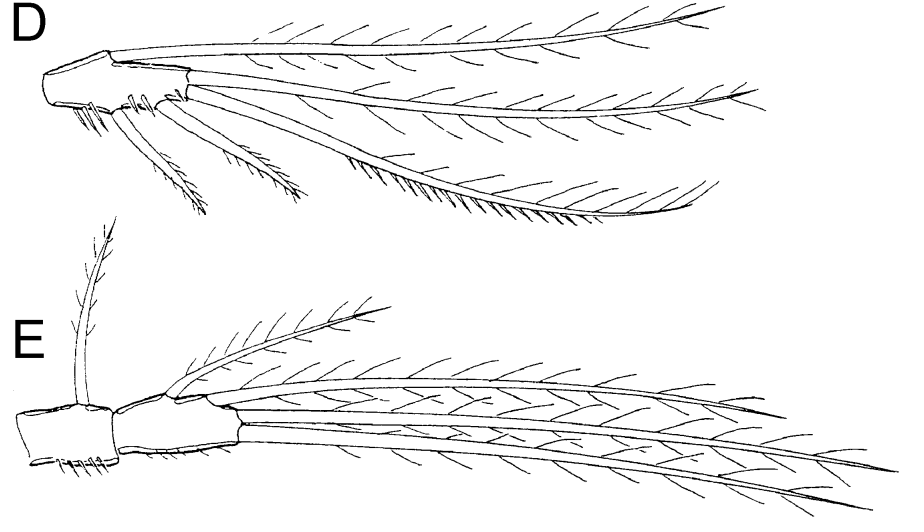

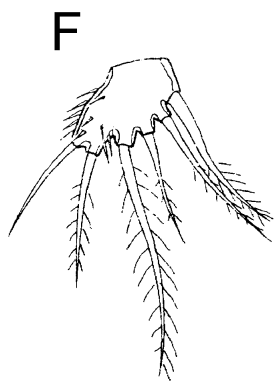

$25 \mu \mathrm{m}$

Fig. 4: Paralaophonte harpagone sp. n. (A) Female anal somite and caudal rami, dorsal. (B) Female urosome, ventral (arrow: copulatory pore). (C) Male second and third urosomite, ventral. (D) Aberrant male P2 exp-3 (paratype), anterior. (E) Aberrant male P3 enp (paratype), anterior. (F) Aberrant male P5 exp (paratype), anterior. 